\title{
The Reflection of Scientific Facts in the Translation of the Qur'an
}

\author{
Bakri Al-Azzam ${ }^{1}$, Muhammad Al-Ahaydib², Hussein Abdo Rababah ${ }^{2}$ \\ ${ }^{1}$ The Hashemite University- English Department, Zarqa, Jordan \\ ${ }^{2}$ Al-Imam Muhammad Ibn Saud Islamic University, College of languages and Translation, Riyadh, Kingdom of Saudi Arabia \\ Email address: \\ bakriazzam2013@gmail.com (B. Al-Azzam),miahaydib@yahoo.com (M. Al-Ahaydib), hrababah@hotmail.com (H. A. Rababah) \\ To cite this article: \\ Bakri Al-Azzam, Muhammad Al-Ahaydib, Hussein Abdo Rababah. The Reflection of Scientific Facts in the Translation of the Qur'an. \\ International Journal of Language and Linguistics. Vol. 3, No. 4, 2015, pp. 193-202. doi: 10.11648/j.ij11.20150304.11
}

\begin{abstract}
The purpose of this study is to explore the possibility of preserving scientific facts in the translation of the Qur'an, as one of its challenging and inimitable features. It should be pointed out that many scientific subject matters, dealt with in the Qur'an, give rise to translation challenges. Such matters are scientifically proven by today's scientific discoveries, but not dealt with sufficiently in translation. Lack of knowledge in many scientific issues results in incompatibility between the translation product and the advanced knowledge of today; this requires that translators of the Qur'an should be equipped with thorough scientific knowledge in order to enable the target text accommodate the source text's scientific facts. The theoretical part of the study is based on the idea that scientific facts in the Qur'an have not been adequately scrutinized from a translational perspective. Most of their efforts focus on the linguistic aspects and literal semantics of the sacred text, stripped from scientific implications. In order to prove the translators' unintended neglect of these facts, a number of translations are examined and enough supporting explanation of scientific resources is provided to show the congruence between what was revealed in the Qur'an before fourteen centuries, and what modern sciences have uncovered. The study draws the conclusion that scientific knowledge in different scientific fields is essential in the translation of the Qur'an, as it is a possible fact that the translator is liable to commit mistakes in the translation of scientific statements if s/he is not expert or specialist in the scientific discipline under question. Therefore, translators should be knowledgeable in all aspects of the Qur'an in order to be able to provide an authentic rendition in the receptive language.
\end{abstract}

Keywords: Scientific Translation, Qur'an Translation, Scientific Facts, Science

\section{Introduction}

Translating the Qur'an into other languages is a challenging task due to many peculiar syntactic, semantic and linguistic features that it enjoys. Dealing with linguistically and culturally based problems is not always demanding, as capturing some co-text meanings can be sufficient, if provided with explanatory details. In other words, translators of the Qur'an are usually concerned with rendering its linguistic and cultural aspects, while delving deep to discover the Qur'an's extra-linguistic values is gratuitous. In order to relay such components, translators should have capacious knowledge in different areas, as the Qur'an is inimitable in historical, psychological, educational, economic, social, and administrative aspects (cf. Al-Najjār 2008:15)

Understanding and interpreting the Qur'an has differed over time, and it still differs from time to another. This gives the possibility of translating the sacred text differently and according to the scientific ground that the commentator may rely on. The Qur'an exegesis at the time of revelation, for example, differs from the exegesis of the $21^{\text {st }}$ century as many scientific theories have been recently proved to be true by modern sciences. This gives modern exegetes and translators alike a solid scientific ground to build their argument on, a situation that was not available during the time of revelation, as what applies to commentators applies to translators who provide their translation on the basis of their linguistic background and Qur'an commentaries. In other words, it is digging in the unseen which complicates the whole issue, and doubles the translation problems. In this regard, Bucaille (2003:4) is quoted as "for many centuries, humankind was unable to study certain data contained in the verses of the Qur'an because they did not posses sufficient scientific means. It is only today that numerous verses of the 
Qur'an dealing with natural phenomena have become comprehensible.......with its compartmentalization of everincreasing knowledge, it is still not easy for the average scientist to understand everything he reads in the Qur'an without having recourse to specialized research. To understand all verses of the Qur'an, one is nowadays required to have an absolutely encyclopedic knowledge embracing many scientific disciplines."

The Qur'an calls its readers to be attentive to how they are created, and contemplate the surrounding environment to perceive the wonders of creation. This is exemplified in the verse (وفي الأرض آيات للموقنين وفي أنفسكم أفلا تبصرون), which Ali (1999:1543) translates as "On the earth are signs for those of assured faith, as also in your own selves: will ye not then see?". This is clear evidence that man should scientifically apprehend and think of the way he is created, and should also give a similar thought to the environment around him, as it glows with many scientific signs. This call is not only for the real believers, who recite the Qur'an on a daily basis, but also for scientists who can regard the Qur'an as a book of science to prove their theories. Indeed, some scientific facts of the Qur'an have been confirmed and made plausible-- thanks to scientific progress, while others are not yet confirmed but should be measured as highly probable. In the meantime, the Qur'an should not be considered as purely scientific, since it is religious par excellence and should not be expected to have a scientific purpose per se (Bucaille ibid:5).

The fact that the translator knows the text before rendering it gives him readiness and preparedness to decipher the material and consider all its linguistic and extra-linguistic dimensions. Translating this form of science-incubating text is less challenging than other text-types, because the meanings are definite and do not hold further semantic possibilities. Translating the Qur'an scientific text is different from translating a text that is entirely technical as the former is not as such patterned, though it includes many scientific examples that can support one of its main inimitable features. Simultaneously, the Qur'an is neither purely ordinary nor is it purely literary, but a joint book of God that hosts many literary and ordinary textual features. This means that translation of the scientific part of the Qur'an requires independent translation attempts to cover this corner of the multi-purpose sacred text.

\subsection{Objectives of the Study}

This study aims at:

1. Exploring the possibility of preserving scientific facts in the translation of the Qur'an into English,

2. Analyzing different translations of Qur'an and find out if these translations have preserved the scientific facts.

3. Investigating the possibility of translating, some scientific facts in the Qur'an into English.

4. Identifying the problems that a translator might face in translating the scientific facts in the Qur'an.

5. Identifying the suitable skills that a translator should have in order to translate scientific facts in the Qur'an.

\subsection{Significance of the Study}

Qur'an readers and exegetes are likely interested in the linguistic meaning of its verses. It should be noted that lack of attention is usually given to the deep scientific meaning of the verses. This dearth of attention has let many recently discovered truths pass unnoticed and uninterrupted in Qur'an exegeses and commentaries. It is the advancement of science and technology that threw its stone in the scientific still water of the Qur'an. The importance and significance of this research paper stems up from the translation of the Qur'an as well as understanding the modern scientific phenomena and facts hidden deep in the meaning of Qur'an. The translation of the scientific meaning in the Qur'an verses were neglected because of the lack of scientific knowledge of the translators. They usually used to focus on the translation of the linguistic side or the superficial part of the verse. However, the superficial or linguistic meaning is as important as the deep or scientific meaning in the total translation process.

\subsection{Methodology}

The researchers have reviewed and analyzed three translations for eight verses of the Qur'an. For the sake of brevity, Roman Numerals are used to designate the three translations. Thus, (I) stands for Ali's translation, (II) stands for Arberry's and (III) stands for Pickthall's. Then they have been analyzed and discussed in order to explore the defects in the translation of scientific facts in Qur'an into English.

The current translation problem will be discussed on the basis of three bona fide interpretations of the Qur'an. The scientific signs, as a translation challenge, will be scientifically discussed and analyzed with reference to these translations, in order to mull over the size of the translation problem. Furthermore, assistance is sought from handful reliable exegeses to lay hands on the translation problem, and suggest a new scientifically-based translation of the verses under discussion. And in order to attest the accuracy of the Qur'anic verses of the study and tighten the argument, reference is made to different scientific studies that endorse the scientific truths explicated in the examples of the study.

\section{Qur'an and Science}

Over the past decades, numerous Muslim and non-Muslim scholars recognized that scientific knowledge is not necessarily neutral and objective, but instead carries values and concepts that are specific to modern Western civilization. This has led to a concerted effort by Muslim scholars to "Islamize Knowledge" but the focus of this effort has been on social sciences. There is also a crucial role played by translation in the history of scientific ideas and the transmission of knowledge (Olohan, M., Salama-Carr, M. 2011). Concurrently, some Muslim scholars working in biomedical and other natural sciences are attempting to show that the Qur'an contains "scientific facts" (Reḥmān 2003). There are passages scattered over the Book which deal with different issues related to creation and provide information 
on the successive events marking its development with varying degrees of detail (cf. Bucaille 1978:133). The modern discoveries which approve the accuracy and truthfulness of the Qur'an have bewildered and thunderstruck many scientists. In this regard, Bucaille (1977:144) says "The scientific truths with which the Qur'an is featured have caused some surprise, as I never thought that the Qur'an has a large number of scientific facts that confirm the modern knowledge and science."

Inclusion of and reference to many scientific facts have given the Qur'an precedence over an ordinary text. This inclusion is not direct or straightforward, but came to indirectly address the scientifically-gifted readers to these signs. The Qur'an, in other words, instructs its readers to "contemplate the (wonders) of creation in the heavens and the earth" (3:191). Throughout the Qur'an chapters, Man is instructed to behold and contemplate in many signs of nature as in the verse: "Behold! In the creation of the heavens and the earth; in the alteration of night and the day; in the sailing of ships across the ocean for the profit of mankind; in the rain which Allah sends down from the skies, and the life which He gives therewith to an earth that is dead; in the beasts of all kinds that He scatters through the earth; in the change of the winds, and the clouds which they trail like their between the sky and the earth, (here) indeed are Signs for the people that are wise" (2:164).

The tight link between the Qur'an, knowledge and science has made the sacred scripture a tool to investigate many scientific fields of biology, astronomy, geology, botany, creation, fetal development, and geology, among many others (cf. Al-Najjār 2008; Hasb Al-Nabī 1996; Abu Al-'Ainain 1996, and Khidr 1993). Conversely, modern secular knowledge contributes to a better understanding of certain verses in the Qur'an which until now has remained enigmatic, if not incomprehensible previously; these passages were obscure owing to the non-availability of knowledge which could help interpret them (Bucaille 1978: ix). Reference to these fields of knowledge is not meant for its very sake, but came to direct the reader and guide him to the omniscience of Allah, on the one hand, and instruct him to think deeply in himself, and in the surrounding environment, on the other. Moreover, modem science is closely linked to translation or, indeed, started as translation (Montgomery 2000:272). The transfer of scientific and technical knowledge across linguistic-cultural borders had considerable linguistic and epistemological consequences, such as the creation of new vocabularies; the deletion and addition of epistemological matter" (Montgomery 2000:269)

The Qur'an has very accurate descriptions of natural and human phenomena. This has led many distinguished scientists in various fields to embrace Islam due to the accuracy concordance between their findings with what many verses describe. Some scientists benefited from their observance of scientifically proved phenomena and what look like "gross scientific flaws" within the Qur'anic text (Cook 1983:68); other scientists have also gone further in their search to prove some scientific miracles by consulting many verses of the Qur'an that describe the same phenomenon, like the verses that illustrate the role of the mountains in the stability of earth (Campbell 1989:170-173), and the creation of heavens from smoke (Neuman and Eckelmann 1977:71-2 and Campbell 1989:22-25) and the different stages of human creation (Campbell 1989:188; Raḥmān 1979:13), as it will be discussed and explained in the following sections.

One of the most Qur'anic textual exclusiveness is that the Qur'an contains many verses which accurately describe natural phenomenon in various fields such as embryology, meteorology, astronomy, geology and oceanography. Scientists have found its descriptions to be inexplicably valid for a book dating from the 6th century; in fact, many of the processes and functions mentioned in the Qur'an have been discovered only recently. This fact alone has been good cause for a number of distinguished scientists to embrace Islam.

Man is awarded an intellect that enables him to uncover many scientific facts. The Qur'an can be a yardstick to achieve such a goal. What is required from the Qur'an's readers is contemplation in its verses, and linking between the content of the verse and what it might designate. Enough research and enough inspection of scientific signs can lead to ever-existing truths. In other words, the Qur'an is encyclopedic as it contains many signs of knowledge about the past, the present and the future. It foretells unknown scientific discoveries, and through its rhetoric and eloquent language directs many to investigate many values. The Qur'an addresses reason and heart of man, in a way that makes its reading congenial and interesting.

The true science and religion do not contradict each other; they, instead, complement each other as one address the genius and the other addresses the heart, and as such they go side by side, as the relationship between them is tight, and this is proved by the fact that they were obtained together by many individuals (cf. Bashkill 1988:145). Thus, the contradiction is not between science and religion, but rather between scientists and religionists as the disagreement between the two sides was for authority monopolization. Science and religion never come to opposing one another, as religion decides the real ideals for the rules of faith that man adapts, while science clarifies the development of life in order to reach, through it, the highest levels (cf. Haikal 1964:9).

\section{Findings, Analysis and Discussion}

Maintaining scientific facts in the translation of the Qur'an is an inescapable challenge, as many religious and scientific disputes can come into view. What makes it indispensably difficult to cover scientific facts in the translation of the Qur'an is the little attention the topic has received if compared with other translation issues. The Qur'an has definitely touched on this modern disputable issue between Muslim theorists who consider the issue as a supporting evidence of Qur'an revelation, and secular scientists who censure it. The study, thus, is a third trend that attempts to 
conciliate between the different views of the disputing parts. It will, moreover, call upon some relevant scientific substantial studies to support the argument and add more authorization to the revelation truthfulness. The present study is hoped to accomplish awareness for translation scholars, exegetes, commentators, and modern science specialists, so that more attention is given to this lively corner of the Qur'an.

After reviewing the translations and the related literature, the researchers have found the following translations and results:

The first example of translation which has been investigated in this study is the verse:

(ألم نروا كيف خلق الله سبع سموات طباقا وجعل القمر فيهن نورا وجعل

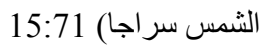

Arberry (1980:303), in Translation (I), has translated it as "Have you not regarded how God created seven heavens one upon another, and set the moon therein for a light and the sun for a lamp".

Ali (1999:1738), in Translation (II), has transacted it as "See ye not how Allah has created the seven heavens one above another, and made the moon a light in their midst, and made the sun as (Glorious) Lamp".

Pickthall (2002:594) in Translation (III) has translated it as "See you not how Allah has created seven heavens in harmony, and has made the moon a light therein, and made the sun a lamp".

The solar system has a boundlessly large number of stars and star-mother orbiting moons. Stars are burning or luminous objects and as such produce light, while moons are not luminous, since they do not give out their own light, but reflect $10 \%$ of the sun's light and absorbs $90 \%$ remaining light (cf. Hasb Al-Nabī 1996:258). The verse under discussion here has shed light on this fact fourteen centuries ago, recording one of the astronomical challenges that have recently ceased to perplex the $20^{\text {th }}$ century scientists. It is clear from this verse that the two exorbitant bodies have their current structure since the very day of their creation. The Arabic verb, 'ja'alā', 'he made' which includes reference to the doer of the action, indicates this truth, as laying down is one of the senses that this verb signifies, a fact that clearly describes the case of the two celestial bodies, at the time they were set.

The collocational relationship between 'qamar' 'moon' and 'nūr', 'light, on the one, and 'shams', 'sun, and 'diyā̄" 'glow', on the other, is intertwined and linguistically observed in many verses in the Qur'an. In other words, the light reflected is associated with the moon, as a cold body while radiation and lamping are some of the sun's associations, as a heat producing body (cf. Mohammad Ali 1993:30; Hasb Al-Nabī 1996:258). This body is a ball of burning gases and as such shines or glows as the gases fuse together. Unless the reader has a scientific sense, he would not grasp the scientific meaning, as an invisible and unseen constituent of the verse. It is, thus, the contemplating and the meticulous reading that enables the reader to observe the unseen and comprehend the clear but the unnoticed meaning. The case being so, the translator cannot escape the dilemma but by considering the literal meaning of the verse, which, though fail to include the scientific value, can elude the reader to scientific discoveries.

As far as translation is concerned, Arberry, Ali, and Pickthall have succeeded in sensitizing the literal meaning, but have not made any allusion to the astronomical indication, which is significantly loaded with meaning. Some supposed reason behind the misconception of the scientific meaning can be the translators' interest in rendering the source language text as a target language corresponding material; this does not require them to toil for other associated meanings that can be particularly discovered by scientifically well-equipped readers. It is also probable that lack of knowledge in this domain has caused this translation drawback, a justification that can defend their case.

Another hypothetical reason for departing the scientific meaning is the absence of scientific findings, at the time of translation that can verify this scientific fact. Some Qur'an commentators have also opted for the literal meaning of the verse, where the scientific fact has not been explained in depth (cf. Al-Șābūn̄̄ 1981, vol.3:447; Al-Zamakhsharī 2005:1143); some commentators have not even explained this literal meaning, but have given the fact that the two bodies have different glowing capacities (cf. Al-Ṭabarānī 2008, vol.6:355; Ibn Kathīr 2003:1525). The translation of an astronomically loaded verse necessitates that the translator should be outfitted with enough knowledge in the domain to maintain the scientific part in the target text.

The second example of translation is the verse:

30:21 (أولم ير الذين كفروا أن السموات والأرض كانتا رتقا فقتقناهما) (1) (1980),

Arberry (1980:19), in Translation (I), has translated it as "Have not the unbelievers then beheld that the heavens and the earth were a mass all sewn up, and then We unstitched them".

Ali (1999:913), in Translation (II), has transacted it as "Do not the unbelievers see that the heavens and the earth were joined together (as one unit of creation), before We clove them asunder".

Pickthall (2002: 30) in Translation (III) has translated it as "Have not those who disbelieve known that the heavens and the earth were of one piece, then We parted them".

The verse in question gives an accurate description of the way the earth was created. This exactness is represented in the idea that that the earth and the seven heavens were once joined or fused together. And in order to make life on the earth possible, the creator has diffused the planet from the sun, as confirmed by astronomers, physicists, and astrophysicist. This scientific cosmic miracle alluded to by the Qur'an fourteen centuries ago has turned true by modern science. Such revelation not only proves the divinity of the text, but also confirms the true foretelling of many scientific events, that began to emerge (cf. Hasb Al-Nabī 1996:350). The fact that the two bodies were joined together is illustrated in the verb 'fataqa', 'to split apart, or 'cleave asunder'.

Moreover, the indication of the tight link between the bodies is clearly noticed in the verb, a link that only a divine body could segregate, in a process known among scientists as 
the Big Bang (Hasb Al-Nabī 1996:342). The Qur'an has employed 'ratqa' and 'fataqa', respectively 'one part', and 'split apart', as appropriate words in Arabic, having the same linguistic pattern; to describe the way the heavens and the earth were attached together. It is only in the last $20^{\text {th }}$ century that astronomers have come to conclude this fact, which confirms that translations of the Qur'an before the discovery are deemed to be inaccurate because of the lack of unawareness of these scientific truisms.

The heavens and the earth are not only celestially related, but also linguistically co-occurring with each other in many verses in the Qur'an. This linguistic signification should have driven the Qur'an interpreters and the Qur'an scientific explorers alike to such a fact in order to trigger the accurate and the exact meaning. The translator inevitably fails to relay this significant part of the text, if he does not give sufficient attention to its various layers. Consulting Qur'an exegeses can be a helpful authority, if enough scientific attention is given by commentators. The problem, however, becomes more complicated if the commentators make no reference to such signs, and the translator does not consult scientific authorities that touch on the particular topic (cf. Ibn Kathīr 2003:955; Al-Ṭabarānī 2008,vol.4:282). On this basis, the translator's task is tripartite; he should have self understanding of the text, consult religious exegeses, and more importantly in the due time, scientifically discuss the area in hand.

The three translators have dealt with the text linguistically, and were misled by the scientific suggestiveness with which the text is budgeted. They have failed to bluetooth a benchmark part of the verse which aims at illuminating one of the Qur'an foretold truths. The translators should have provided the translations with footnotes that can compensate the loss of the scientific meaning, in order to minimize the scientific unbridgeable gap, which they are not blamed for as scientific facts are sometimes unknown by even specialists of the scientific field.

What is interesting in the issue is that the scientific facts of the Qur'an are distributed all over the Book, and they look as fortuitous to convey the message that the verses of the Qur'an are ambushed by scientific miracles, and the reader should have enough awareness of the material he is reciting. In a very artistic and complex language, the Qur'an employs the scientific notions to conduct the dynamical feature of the Qur'an that makes it appropriate for all times and generations. The translator should experience literary, scientific (the heavens and the earth joined together, in this example, (cf. Hasb Al-Nabī 1996:350), and theological readings (AlȘābūnī 1981,vol:261; Al-Zamakhsharī 2005:677) in order to grasp as much as possible of the multi-function text.

The third example of translation is the verse:

88:27 (و نرى الجبال تحسبها جامدة وهي تمر مرَ السحاب) (1980:84),

Arberry (1980:84), in Translation (I), has translated it as: "And thou shalt see the mountains, that thou supposest fixed, passing by like clouds)"

Ali (1999:1090), in Translation (II), has transacted it as "Thou seest the mountains and thinkest the firmly fixed: but they shall pass away as the clouds pass away".

Pickthall (2002:358) in Translation (III) has translated it as "And you see hills you deem solid while they are flying the flight of clouds".

Mountains and clouds are similar in the shape they bring to mind, and the shape they form. However, the paradoxical relationship between them is that while the mountains are solid, heavy, stable and deeply rooted, the clouds look light, flimsy, unsubstantial, and easily driven by winds. Enclosed and surrounded by mountains, many people strongly believe that mountains are strongly fixed, and being denoted otherwise is something mythical. The modern geologists have found out that the huge mountains can change to be small hills due to weathering and erosion factors. Because of the hot currents pushed up from the burning bottom of the earth, the earth crust is folded once and again to form new series of mountains that replace the earlier ones. Thus, the series that man can observe these days are different from the ones created, in terms of morphological appearance and geological age (cf. Abu Al-'Ainain 1996:156).

Interpreting the verse linguistically and linking it to the previous one, which describes the Day of Resurrection, a reader can decide on the literal meaning of the verse where the solid mountains of today would become very weak. Not only ordinary people, but also the Qur'an exegetes can interpret similarly and refer the case of the mountains to that day; they may depend on the context of the verse, where the interpretation is supported by the previous verse which portrays the pandemonium, and the uproar of the witnesses.

One of the inimitable features of the Qur'an is its stylistics, where the near meaning which expresses the case of the mountains on the Day of Judgment, is originally secondary, as the meaning implied is the scientific one, which refers to the mountains of this life. Seeking help from this context, readers of the Qur'an and exegetes alike have failed to misinterpret the text on a scientific basis, which has demonstrated that the mountains are in a continuous movement, and replacement of each other.

Translators of the Qur'an rely heavily on their understanding of the text on one hand, and the Qur'anic exegeses, on the other. Any inaccuracies in the Qur'anic interpretations will inevitably lead to erroneous translations, especially when the text under discussion is injected with a scientific fact. Arberry, Ali and Pickthall have respectively rendered the scientific fact of mountains movement as "shalt see the mountains passing by like clouds, shall pass away as the clouds pass away, and flying the flight of clouds". These literal translations have implicitly referred to the other day, without giving any indication that the mountains of today are coming through the same experience.

The translators could have relied on interpretations that have not given any mention to this fact (Al-Ṭabarānī 2008, vol.5:46; Ibn Kathīr 2003:1095). Lack of knowledge at the time of interpretations and translations, and taking no remedies of specialists in the field of geology could have led to such mistranslations of the scriptural text; in other words, translators of the maintaining-scientific-fact verses should 
enjoy not only linguistic, but also scientific competence, as literal translation is sometimes insufficient in producing a target language equivalent that can reflect all the components of the source text.

The fourth example of translation is the verse:

6:37(يخلقكم في بطون أمهاتكم خلقا من بعد خلق في ظلمات ثنلاث)

Arberry (1980: 351) in Translation (I), has translated it as: "He creates you in your mothers' wombs creation after creation in threefold shadows".

Ali (1999:1341) in Translation (I), has translated it as: "he makes you, in the wombs of your mothers, in stages, one after another, in three veils of darkness".

Pickthall (2002:441) in Translation (I), has translated it as: "He created you in the wombs of your mothers, creation after creation, in a threefold gloom".

The fact that no medical devices were invented during the Prophet's lifetime made it impossible to observe the three veils of darkness that cover the fetus or the unborn child. The three veils have been scientifically proved by modern medical research. The accuracy and precision of the case description can be clearly noticed in the Qur'an, where an extreme truthfulness of the gradual physical growth is observed by biologists and medical scientists. Readers of the verse till a later time could have understood the three veils literally, where an exaggeration of the darkness is thought to be manipulated by the reference to the three veils. Readers and exegetes of the Qur'an would have not understood or interpreted the religious text without reference to scientific studies that can view the fact.

Thus, misunderstanding of the text could have driven the readers and exegetes to provide erroneous or implausible interpretation, as they rely heavily on the literal or linguistic ground of the text. Reference to scientific facts is a stylistic feature of the Qur'an, which can be considered as a source of inimitability in text composition or text translation. What makes grasping the scientific facts in the Qur'an a hard task is illustrating them in a simple manner that does not attract the reader's attention to give them enough thinking. Moreover, the indirectness of conducting the scientific fact causes it to pass unnoticed, as commentators and readers often try to linguistically explain the various meanings of the Qur'anic verses.

Incompleteness in the verses interpretations arises from the lack of scientific grounds. Some commentators are very careful in explaining the meaning; fearing to provide incomplete or erroneous commentaries results from the unawareness of the scientific implications that the verse may attain. In order to defend their view, exegetes are not strong or direct in their explanation, as they indicate probabilities and possibilities in presenting the scientific data. To illustrate, the three veils are conducted they probably refer to the belly, womb and the hollow in which the womb is enclosed (cf. Al-Zamakhsharī 2005:934; Al-Ṣabūn̄̄ 1981, vol.3:71).

The translations of the Qur'an are not deemed to be completely true, as most translations are based on the Qur'an exegeses besides the translators' linguistic potentials.
Provision of explanatory details is necessary, so that target language readers can have enough understanding of the source text. In the selected translations, only Ali footnotes his translation with supporting details to elucidate the scientific meaning; thus, he maintains that the three veils of darkness that cover the unborn child are: the membrane, the womb, and the hollow in which the womb is enclosed, but we might understand "three" in a cumulative rather than a numerical sense.

However, "threefold gloom" in Pickthall translation has neither relayed the linguistic meaning where "darkness' is not necessarily 'gloom", nor the scientific fact where scientific details are not provided. In order to create a reliable translation of the verse under discussion, translators should consult scientific studies in the field, where the three veils are explained as follows: the Amnion, the Chorion, and the Decidua form the first darkness; the womb forms the second darkness; the body which consists of one's belly and back forms the third darkness (cf. Al-Najjār 2008:127-8).

The fourth example of translation is the verse:

12:65 (الله خلق سبع سموات ومن الأرض منلكن)

Arberry (1980:286) in Translation (I), has translated it as: "It is God who created seven heavens, and of earth their like".

Ali (1999:1686) in Translation (I), has translated it as: "Allah is He Who created seven firmaments and of the earth a similar number".

Pickthall (2002:573) in Translation (I), has translated it as: "Allah it is who has created seven heavens, and of the earth the like thereof".

Geological studies following the revelation of the Qur'an did not exist; the Qur'an, however, refers in many situations to geological scientific facts. The accuracy of the scientific signs in the Qur'an confirms its divinity, and the precision of the information tells the cognizance of the Qur'an revealer. Allah has created seven heavens, as is clear in many Qur'anic verses, and the same number also applies to the earth. The lack of geological science at the Prophet's lifetime has bewildered people, as it can never happen that there are seven heavens and seven earths.

Readers of the Qur'an and commentators alike have to conduct enough exploration in order to arrive at this unprecedented fact, where the seven earths are verified by the modern science. Before the scientific findings, it was difficult for the minds to absorb how the seven earths are created, and if created, why people cannot observe them. Modern geophysical studies have provided evidence that the earth consists of seven layers, with different depths and structures (cf. Abu Al-'Ainain 1996:100; Mohammad Ali 1993:58), and not seven planet earths, as most readers of the Qur'an may anticipate.

The lack of geological knowledge at the time of revelation, and the successive centuries has made it difficult to scientifically explain the fact that the earth consists of seven layers, one above another. This shortage of knowledge about this sign has led either to incomplete commentaries, or to erroneous ones; incompleteness has resulted from the literal 
explanation of the verses holding scientific signs, where exegetes and Qur'an commentators ceased to provide details exceeding the surface level of the text. The scant attention to the layered meanings is attributed to the human failure to explore and investigate any further possible meanings. Thus, updating the Qur'an commentaries and exegeses is necessary in order to cope with the new discoveries, as only in this updating Qur'an exegeses can show the extra-linguistic features of the Qur'an.

The three translators have opted for the literal meaning of the verse under discussion. They have managed to convey this meaning, but at the expense of the enlightenment of other textual constituents. If it is difficult to include more details in the body of the translated text, for reasons related to size congruence, for example, the translator has to support the translation with necessary information in footnotes. This helps the target language reader to grasp more details about the source text. Abdul-Raof (2001:166) maintains that it is of great importance and value to the target language audience that Qur'anic structures with scientific fats are explained in a footnote. Though this translation procedure violates the source text size, it helps in compensating the loss of not reflecting the science of the verse, as a substantial element.

The problem, however, arises when the translator is unaware of the scientific value, which is neither discovered by scientists, nor thus explained by exegetes who build their explanation on scientific grounds. Arberry, Ali, and Pickthall have managed to show large part of the meaning, thanks to their linguistic competence, on the one hand, and reference to exegetes, on the other. They have unintentionally missed the source text scientific value. Had they known that the earth consists of seven layers, they would have not ignored referring to them, as capturing such an elemental part is a translation achievement that they are to be proud of.

The sixth example of translation is the verse:

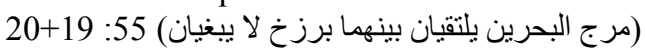

Arberry (1980:251) in Translation (I), has translated it as: "He let forth the two seas that they meet together, between them a barrier they do not overpass".

Ali (1999:1588) in Translation (I), has translated it as: "he has let free the two bodies of flowing water, meeting together, between them a barrier they do not transgress".

Pickthall (2002:534) in Translation (I), has translated it as: "He has loosed the two seas; they meet. There is a barrier between them. They encroach not (one upon the other)".

The unusual marine life and the living species have made exploring water depths a fertile area for oceanic studies. The huge variation of sea creatures and plants, fish, salinity, currents, and darkness, to mention but a few, has urged scientists to conduct groundbreaking studies that have uncovered a small number of sea secrecies. For people living in deserts or desert-like regions, telling about a barrier between sea waters is mind-boggling; dearth of scientific knowledge at the time of the Qur'an revelation, and the successive phases has not helped the Qur'an readers and commentators to apprehend the accurate scientific meanings of the verse under discussion.
One of the inimitable features of the Qur'an is its scientific stylistics, which is illustrated in setting forth scientific examples in different chapters that readers thoughtlessly skip them over. This inattentiveness has left many scientific signs to pass unnoticed by Muslim scholars till they were lately proved by modern sciences. Reference to the barrier between sea waters in different chapters of the Qur'an aimed at indirectly drawing the readers' attention to investigate the scientific sign.

The Arabic lexical item 'maraja' 'caused to meet' has plainly referred to water mixture of seas and oceans. However, it does not, by itself, inform the way through which they mingle together. The rest of the verse has pointed out that water currents of different seas and oceans go side by side, and keep independent form each other to an extent that their living creatures remain in their water realm. Surprisingly enough, the sign has been recently discovered after the elapses of more than a decade of centuries. The presentation of the verse and the way of delivering the scientific fact have bewildered the readers of the Qur'an, commentators, exegetes, linguists, translators and, scientists, may be. The indirect references to the miracle, and the inimitable choice of diction, have helped the science to lie in wait of specialists to find.

Therefore, different interpretations and commentaries of the Qur'an were provided to linguistically analyze the verse in question; some of the commentaries have provided inaccurate explanations (cf. Ibn Kathīr 2003:1419; Al-Șabūn̄̄ 1981,vol.3:287), where the separation of the waters is explained on the basis of the landscape between the oceans; salt and sweet waters were caused to run underground, and are not allowed to approach one another when they meet (cf. Al-Tabarāni 2008,vol.6:169); or the water separation of the two meeting sees cannot be observed by the naked eye (cf. Al-Zamakhsharī 2005:1070).

The translator of the Qur'an heavily relies on the commentaries and exegeses. In order for them to provide accurate commentaries, exegetes should consult scientific findings that prove the accuracy and precision of the Qur'an's scientific sign. The translator's task becomes more long-winded and convoluted. $\mathrm{He}$ has to be a linguist to comprehend the linguistic aspect, a religious scholar to understand the divinity of the text, and a scientist in various fields to prove the exactness of the Qur'an scientific facts. The three translations have successfully relayed the linguistic part of the text, but only Ali (1999:1588) has pinpointed the scientific element by saying "the two bodies of water, salt and sweet, meet together, yet keep separate, as if there was a barrier or partition between them". Reference to the fact by 'as if' in Ali's footnotes shows his uncertainty, and the selfindependence of the verse comprehension. This can lead to the conclusion that sufficient reference to scientific studies is necessary for the translator to provide a reliable translation. Thus, the translation versions should be supported by the scientific evidence that seas meet together, but their water currents keep independent and do not transgress borders (cf. Mohammad Ali 1993:73; Hasb Al-Nabī 1996:191; Abu Al- 
'Ainain 1996:259).

The seventh example of translation is the verse:

22:15 (وأرسلنا الرياح لو اقح فأنزلنا من السماء ماء) (1980:282)

Arberry (1980:282) in Translation (I), has translated it as: "And We loose the winds fertilizing, and We send down out of heaven water".

Ali (1999:710) in Translation (I), has translated it as: "And We send the fecundating winds, then cause the rain to descend from the sky".

Pickthall (2002:232) in Translation (I), has translated it as: "And We send the winds fertilizing, and cause water to descend from the sky".

Lack of meteorological knowledge in the earlier Islamic era and the successive ones has led to incomplete or inaccurate commentaries and interpretations of the Qur'an. The verses that inform the way the rain falls from heaven could have been interpreted figuratively, where the soil is pollinated by the rainfalls, causing different types of plants to grow. Thunders and lightening could have been explained as natural phenomena, where the positive and the negative charges are not factors of causing the whole process to happen.

The verse under discussion can be literally, figuratively, aesthetically and scientifically analyzed. As Ali maintains in the footnote (1999:710), the wind performs the office of impregnation or fecundation for many flowers; here, the wind's fecundating quality is transferred to the clouds, which by means of rain produce all kinds of fruit, grain, and vegetation. The clouds as vapor are manipulated by the winds, which set up atmospheric currents resulting in condensation and the descent of rain. Since the translator does not have a scientific ground to build his argument on, he has alluded to the figurative and literary understanding of the verse. Inaccuracy and imprecision of the interpretation are caused by the dearth of reliable information that can provide a concrete exegesis of the verse.

The clear relationship between the two main parts of the verse gives a clue that as soon the charged winds rasp with clouds, rain starts to fall down. Ignorance of the positive and the negative charges, the reasons behind the lightening and the thunder, and the direct rainfall has made a scientific explanation of the natural phenomenon a far-fetched goal. The linking ' $\mathrm{fa}$ ' is not superfluous but semantically functional in a calculated manner, as it indicates the sudden and the quick response of the clouds after pollination.

After the scientific revolution that the world has witnessed at modern times, the Qur'an exegetes and translators alike should seek remedy from modern scientific findings to prove the precise foretelling of the meteorological signs. Reference to the scientific discoveries confirms the truthfulness of the Qur'an, on the one hand, and urges scientists and scholars to delve deeply beyond the scriptural-textual level, on the other. Through the thorough reading of the text, scholars can realize the meticulous accuracy in the choice and placing of a word, where lawaqih, the plural of laqih, in the example under discussion, is precisely positioned and functioned without directly telling the reader what is pollinated by the winds.

Arberry and Pickthall rendered the Arabic lexical item 'lawāqih' as 'fertilizing', while Ali relayed it as 'fecundating'. The translators have opted for the literal meaning of the text without scratching the scientific implications that the verse may indicate. The translations could have consulted the Qur'an exegeses, which explained 'lawāqih' as pollinators of clouds which consequently pollinate trees (cf. Al-Tabarani 2008, vol.4:44; Al-Ṣābūn̄̄ 1981, vol.2:108; Ibn Kathīr 2003:800; Al-Zamakhsharī 2005:560). As the translations have not fulfilled the ambitions of readers who are in search of scientific facts in the Qur'an, seeking help from exegeses that point out this fact of pollination is necessary (cf. AlSha'rāwi 1991, vol.12:6677). If the exegeses do not have explanations of the fact under discussion due to its discovery, studies discussing the fact from a religious-scientific perspective can be consulted (cf. Mohammad Ali 1993:86; Hasb Al-Nabī 1996:193; Abu Al-‘Ainain 1996:208).

The eighth example of translation which has been investigated in this study is the verse:

(أيحسب الإنسان أن لن نجمع عظامه بلى قادرين على أن نسوي بنانه) 75: $4+3$

Arberry (1980:313) in Translation (I), has translated it as: "What, does man reckon We shall not gather his bones? Yes, indeed; We are able again to shape his fingers".

Ali (1999:1768) in Translation (I), has translated it as: "Does man think that We cannot assemble his bones. Nay, We are able to put together in perfect order the very tips of his fingers".

Pickthall (2002:608) in Translation (I), has translated it as: "Does man think We shall not assemble his bones? Yea, surely, We are able to restore very finger prints!".

The scientific miracles of the Qur'an have extended to include man. Man has been created extraordinarily and inimitably, as clearly proved in the formation of the fingerprints. Scientifically and criminally confirmed as such, the geometric formation of the fingerprints has helped in person's identification, and revealing criminals; the finger images and contours are used to compare between people, and identify wanted persons. Man is addressed in the verse to beware this fact, and observe that his resurrection or recreation is not difficult, as the creator has created the fingerprints in a very accurate manner; they are formed by the tiny edges on the soles of the feet and the palms of hands. The fingerprints are very hard to change even if one tries to make certain modifications, a fact that has been of great help to the police. The different designs of the ridges on the fingers have made fingerprints different; the designs could be dots, angles, islands, broken ridges, looping ridges, bifurcations among many others. Not only that, but also the size, shape and length of the fingers have been created differently in order to enable the human hand to grasp things.

The translators seem to have very likely relied on the commentaries of the Qur'an in rendering the verse under discussion. Relaying the literal meaning of the text transmits its linguistic part, and ignores the implied scientific fact. Translators of such a text should have excreted enough efforts to guarantee echoing enough meaning in the target language. However, the three translations have failed to 
transfer the scientific sign with the translated version. Had the translators been aware of the fact, they would have pointed it out. Arberry and Pickthall have opted for the literal meaning, and have not made any reference to the extralinguistic values, related to the scientific miracle, while Ali added in the footnotes that the meaning of the verse is idiomatic to show the creator's craft in producing the most delicate parts of the body. To sum up, on the basis of the aforementioned discussion, it can be argued that reference to scientific Qur'anic matters is so vital a task for the translator to produce a reliable, authentic, thorough, subtle, proper, educated and appropriate translation.

\section{Conclusions and Recommendations}

This study has investigated the possibility of translating, into English, some scientific facts in the Qur'an. The study has also shown that the scientific facts are hidden deep in the Qur'an, as the source sacred text. The translator of scientific signs in the Qur'an is normally faced with many translation perplexities and confusions, which made the translation of these facts into English a laborious task. The main point of the discussion accentuates the fact that translators should have enough extrapolation and cognition of the scientific dimension of the religious text, in order to capture as much as possible of the layered meanings of divine text.

As far as the analysis of the three selected translations is involved, the discussion revealed that, owing to the daunting complexity of incompatibility between the translators' scientific knowledge and the scientific facts of the Qur'an, the translations have only managed to maintain the textual substance, but have not conveniently captured its scientific implications. Accordingly, it can be generally concluded that the Qur'anic scientific features can provide a suitable area for analyzing, interpreting and explaining an essential part of the Qur'an that may translationally look completely new, to contemporary translation studies.

Knowledge of scientific data is necessary to achieve a reliable translation of the Qur'an; for the relationship between all components of scripture is organic; any translation loss or mistranslation of the sacred text results in deceiving the target language reader who is eager to have reliable information about such an extraordinary text. The translator has to be a Qur'an reader, exegete, and scientist to produce a steadfast version that can gain the approval of the receptive language reader. Bucaille (2003) maintains that some passages of the Qur'an, especially those related to scientific data are badly translated and interpreted, so that target language scientist reader has every right to make criticisms-with apparent justification that the Qur'an does not deserve to be read. Inaccuracies in translation or erroneous commentaries (the one is often associated with the other), which would not have surprised anybody one or two centuries ago, offend today's scientists.

Therefore, the exegeses of the Qur'an should be updated from time to time to include the new discoveries. The early time exegetes, for example, have failed to relay the real intended meanings, related to science and technology. In their turn, translators of the Qur'an, who rely heavily on exegetes' commentaries, fall short before conveying the scientific meaning. On this basis, the exegeses and the translations of the Qur'an should make reference to modern scientific discoveries, in order to preserve faithfulness and truthfulness of the sacred text.

Translators of the Qur'an should, moreover, have a scientific, critical and meticulous reading in order to have a modern understanding that is enhanced by logical and reasonable comprehension. Relying only on the exegetes' commentaries is insufficient to achieve this goal, as some commentaries are not based on scientific methodology, and some others are conducted by scholars who have not witnessed the most advanced scientific and technological findings. Bucaille (ibid) stresses the fact that those commentators are excused to have given an inappropriate definition to an Arabic lexical item that contains several possible meanings; their misunderstanding of the real sense of the word or phrase has become clear at present thanks to scientific knowledge. However, modern interpretations of the Qur'an benefit from the modern technologies, and commentators provide their exegeses with scientific details that can prove the Qur'an as a sacred text which has scientific miracles. Abdul-Raof (2001:169) maintains that Muslim scholars believe that the Qur'an is a scientific miracle, and a number of scientific findings have been verified by modern scientific developments. Thus, the translator has to provide the target text audience with the Qur'anic structures that demonstrate scientific facts

Reserving scientific facts in the translation of the Qur'an is very unlikely attainable as translators are mostly concerned with its linguistic and semantic content. They aspire to produce a congruent textual material without harassing further lurking implications, which can embrace unexplored facts. Therefore, the Qur'an translator needs to have the following skills:

1. S/he should be skilled and knowledgeable in many scientific areas,

2. $\mathrm{S} /$ he needs have exceptional linguistic abilities as scientific facts of the Qur'an prowl behind the linguistic surface; in addition to possessing linguistic and literary sense,

3. The translator has also to have power over the scientific sense of the textual material. Qur'anizing knowledge through translation requires concerted efforts, as the translator is in ebb and flow between preserving the textual material of the

4. $\mathrm{S} /$ he should be able to illuminate scientific accuracies in translation which would probably merit a few raised eyebrows for the first time, as linking a historical sacred text to newly discovered scientific facts may prove implausible.

5. The translators should be able to contextualize the text in the modern scientific discoveries, in order to benefit from the most recent discoveries that can lead to more translation reliability. 


\section{References}

[1] Abdul-Raof (2001) Qur'an Translation: Discourse, Texture and Exegesis. Curzon Press: Surrey.

[2] Abul-Ainain, H (1996) Min al-I‘jāz 1-'Ilmī fi l-Qur’ān. Maktabat 1-Ubaikan: Riyadh.

[3] Ali, A (1999) The Holy Qur'an: Translation and Commentary. IPCI, Islamic Vision: England.

[4] Al. Najjār, Z. (2008) min 'Āyāt 1-'Ijāz l-'lmī fì Khalq 1-Insān fi 1-Qur’ān 1-karīm. Dār il-Ma'rifa: Beirut.

[5] Al-Sha'rāwī, M. (1991). Tafsīin al-Sha'rāwī. Vols.1-13. Dar Akhbār Al-Yawm. Al- Azhar: Ciro.

[6] Al-Zamakhsharī, A. (2005). al-Kashshāf. Dār 1-Ma‘rifa: Beirut.

[7] Arberry, A, J (1980) The Koran Interpreted, vols. 1-2. London: George Allen and Unwin: London

[8] Baskill, A. F (1988) Mawqif d-Dīn mina 1-'Ilm. Trans. by Mohammad Ali, O. ( ${ }^{\text {nd }}$ edition). Dar l-Anbār for Printing and Distribution: Baghdad.

[9] Bucaille, M (2003) The Bible, The Qur'an, and Science: The Holy Scriptures Examined in the light of Modern Knowledge, New York: Tahrike Tarsile Qur'an, Inc: New York.

[10] Bucaille, M (1978) The Bible, The Qur'an and Science. Trans. from French by Pannell, A and Bucaille, M. Crescent Publication Compamy: India.

[11] Bucaille, M (1977) al-Qur'ān al-Karīm, at-Torāh, al-'Injīl, and al-'Ilm: Dirāsat 1-Kutub 1-Muqaddasa fì Dū' 1-Ma‘ārif 1Ḥadītha: Dār l-Ma‘ārif: Cairo.

[12] Byrne, J. (2012) Scientific and Technical Translation Explained: A Nuts and Bolts Guide for Beginners, Routledge

[13] Campell, W. F (1989) The Qur'an and the Bible in the light of History and Science. ( $2^{\text {nd }}$ edition). Middle East Resources, (French edition: France, Farfel editions), ISBN: 1- 881085-007\& 2-86314-077-9).
[14] Cook, M. (1983) Mohammad. Oxford University Press: Oxford.

[15] Dress, W. B (1996) Religion, Science and Naturalism. Cambridge University Press: Cambridge.

[16] Haikal, M. H (1964) al-'Īmān wa l-Ma'rifa wa l-Falsafa. (2 $2^{\text {nd }}$ edition). Maktabat 1-Nahụa 1-Mișriyya: Cairo.

[17] Hasb Al-Nabī, M (1996) al-Kawn wal-I'jāz l-'Ilmī li l-Qur'ān. Dār l-Fikr l-'Arabī: Cairo.

[18] Krein-Kutiile, M. (2003) Equivalence in Scientific and Technical Translation: A Text-in-Context-based. Study PhD Dissertation, European Studies Research InstituteSchool of Languages, University of Salford- Salford, UK.

[19] Khidr, A (1993) Tiknolojya 1-Fad ā 1-Kawnī wa 1-'I'jāz 1'Ilmī li 1-Qur'ān 1-Karīm. Saudi Publishing and Distribution House: Saudi Arabia.

[20] Mohammad Ali, M. S (1993) al-'Ijāz 1-'Ilmī fi l-Qur'ān 1Karīm. Dār 1-Maḥabba: Damascus.

[21] Montgomery, S.(2000) Science in Translation: Movements of Knowledge through Cultures and Time, The University of Chicago Press: Chicago.

[22] Newman, R., Perry, Ph. and Eckleman, H. (2007) Genesis one and the origin of the Earth. Published by Interdisciplinary Biblical research Institute. USA.

[23] Olohan, M. and Salama-Carr, M. (eds.) (2011) Special Issue: Science in Translation, The Translator, Volume 17, Number 2, ST Jerome Publishing.

[24] Pickthall, M. M (2002) The Meaning of the Glorious Qur'an. Amana Publications: USA.

[25] Raḥmān, F (1979) Islam. (2 $2^{\text {nd }}$ edition.) University of Chicago: Chicago.

[26] Rehmān, J. (2003) Searching for scientific facts in the Qur'an: Islamization of Knowledge or a new form of scientism? Islam and Science. , vol. 1. iss. 2. Centre for Islamic science.

[27] Wright, S. (1993) Scientific and Technical Translation, John Benjamins Publishing. 